\title{
News translation in the digital age: A case study of Vice.com
}

\begin{tabular}{|c|c|}
\hline ARTICLE INFO & ABSTRACT \\
\hline $\begin{array}{l}\text { Article history: } \\
\text { Received Sep 28, } 2018 \\
\text { Revised Jan 02, } 2018 \\
\text { Accepted Jan 02, } 2019\end{array}$ & $\begin{array}{l}\text { Translation-mediated events get circulated globally through the } \\
\text { media. This paper focuses on studying how events in, about, and } \\
\text { pertaining Indonesia in general are presented to the foreign audience } \\
\text { through translation. To that end, this paper employs descriptive } \\
\text { product-oriented approach and translation transformation strategies }\end{array}$ \\
\hline $\begin{array}{l}\text { Keywords: } \\
\text { News Translation, } \\
\text { Adaptation, } \\
\text { Re-Contextualization }\end{array}$ & $\begin{array}{l}\text { adapted from those proposed by translation scholars. The data were } \\
\text { collected from an online media, VICE Indonesia, and were limited to } \\
\text { Indonesian source texts and their English target texts published in } \\
\text { November } 2018 \text {. Following initial data collection, } 10 \text { pairs of target } \\
\text { and source texts were compiled for comparative analysis. Data } \\
\text { analysis revealed that adaptation and re-contextualization of target } \\
\text { texts occurred. They are found most prominently in the title and lead }\end{array}$ \\
\hline $\begin{array}{l}\text { Clonflict of Interest: } \\
\text { None }\end{array}$ & $\begin{array}{l}\text { the target texts' contents also experience similar changes. Among } \\
\text { these changes, the most noticeable are recomposition of paragraphs, } \\
\text { omission and substitution or paragraphs, and different choice of }\end{array}$ \\
\hline $\begin{array}{l}\text { Funding: } \\
\text { None }\end{array}$ & $\begin{array}{l}\text { source of quote. Ultimately, although the target texts maintain to } \\
\text { some degree of semblance to the source texts, new realities and } \\
\text { perspectives emerge as the result of these translation strategies. }\end{array}$ \\
\hline
\end{tabular}

Corresponding Author: Annisa Cinantya Putri, Translation Studies, Department of Linguistics, Faculty of Humanities, Universitas Indonesia, J1. Prof. Dr. Selo Soemardjan, Kampus Universitas Indonesia, Depok, Jawa Barat, 16424, Indonesia. Tel: 62-815-8424-7579. E-mail: annisacputri@gmail.com

Copyright (C) Association of Language Teachers in Southeast Asia. All rights reserved

\section{INTRODUCATION}

\subsection{Background}

The practice of translation has always been a part of journalism and it takes place throughout the entire process of news production from information gathering, collating, to disseminating and interpretation of news (Holland, 2013; van Doorslaer, 2010). That Indonesian audience, whether readers or viewers, are consuming news originally supplied by international news agencies is unsurprising as it is how media outlets obtain their information on events that take place outside of the country both near and far. But as the world becomes more globalized and with the rise of digital technology news reports are being circulated at an unprecedented rate around the world, where an event occurring in one place can almost instantly captured and disseminated to, virtually, everyone.

However, news translation is hardly about the translator and the translator's discretion on how to do the translation work, namely to transform a text from one language to another (Colina, 2015). In this field the translator must take into account the editorial policies of the media she/he translates for and the media's stance of an issue (Chen, 2011). The reason is because a media text is never a direct representation of realities or merely presenting a collection of facts, but is actively constructing realities (Gambier, 2006). Numerous studies have pointed out how the media shapes the way we perceive reality, including our attitude, behavior, even decision-making referred to as 
the media effects. In light of this, it is suffice to say that media production is a highly complex work, which is heightened when translation is thrown into the mix. To whom does a translated news article speak, and what gets translated? There may also be a question of translator's loyalty to the target readers, or the media's narrative? And how does the notion of equivalency take hold in this type of translation? Equivalence has always been at the heart of translation debate, but given the complexity of news translation, translated news articles may challenge this notion, as noted by Holland (2006) who studied the bilingual speeches delivered by former president B.J. Habibie with respect to the East Timor referendum.

In Indonesia, news translation seems to play an increasingly notable role. Based on empirical observation, it can be seen that more media outlets are setting up their own separate foreign language website pages that are linked to the original websites in Indonesian. Tempo.co, Kontan, Kompas, even the national news agency Antara have all launched their English websites. The choice of translating their news is an interesting pivot from their traditional root of producing and circulating news exclusively in Indonesian. It may indicate an expansion of readership and may also be an attempt to control what is being translated and how.

Unlike these media that only in recent times adopt Indonesian-English format, Vice.com entered the Indonesian market on 1 November 2016 as a bilingual digital media. This platform was originally founded by Suroosh Alvi and Shane Smith as Vice magazine based in Montreal, Canada. Its enterprise form, Vice Media LLC, was incorporated in 1994. After a predominantly North American operation, in June 2016 it announced its digital and TV expansion to more than 50 countries including Indonesia. According to dailysocial.id, Indonesia was considered an attractive market for Vice thanks to the country's youthful demography (https://dailysocial.id/post/mediamuda-vice-hadir-di-indonesia-untuk-ekspansi-pertamanya-di-asia-tenggara). Vice.com is known for covering unconventional topics - in the Indonesian context this would refer to its reporting about the gay community (see, e.g. https://www.vice.com/id_id/article/gve8zx/pengalaman-gay-diindonesia-melela-pada-orang-tua), for example, or the communist party (e.g. https://www.vice.com/id_id/article/3kepn8/pengakuan-sosok-di-balik-produksi-film-propaganda-

pengkhianatan-g30spki), or the people behind the debt collecting business who are notorious for their propensity to violence when carrying out their work (https://www.vice.com/id_id/article/7xmave/orang-orang-maluku-dan-keberanian-menjalani-

profesi-penagih-utang). As a bilingual media, articles published on Vice.com are translated from Indonesian to English and vice versa. This bilingualism used to mean that the English and Indonesian webpages mirror each other and could provide one-to-one traceability of Indonesian and/or its English news texts. It slightly changed, however, when the media company decided to expand to Asia Pacific and merged the Vice.com Indonesia (hereinafter VICE Indonesia) English page to the Asia Pacific platform. With the change, VICE Indonesia now only offers articles in Indonesian, both written originally in Indonesia and English-language articles translated into Indonesian, while English translation of Indonesian articles are made available on the Asia Pacific website. The type of news that VICE Indonesia produces and circulates falls into the soft news category as proposed by Reinemann, et.al (2011), in which soft news are defined as news that are politically less relevant, represented in an episodic way, focused on individual consequences of events, and are personal and emotional in style. BBC defines it as feature writing, which refers to a longer piece of writing that discusses an issue in greater depth or is an ongoing story of an issue (https://www.bbc.com/bitesize/guides/zqt7k7h/revision/1).

\subsection{News translation research}

News translation research according to Valdeón (2015a) is in the early stage but is important to study considering the effects translation can bring to news discourse. News translation is not without its challenges. Holland (2013) stated time pressure, resources, linguistic constraints, and the pervasiveness of the English language - a challenge for non-English speaking media that feel compelled to translate their content into English in order to speak to an international audience. However, as Holland noted, some media would be better positioned to do this than others. Another challenge that Holland identified and is crucial is the challenge of objectivity and accuracy. Despite 
the intention of impartiality, translators are faced with the inevitable problems, such as of loss and gain, and have to make difficult decisions to solve them.

Having considered all of the above, this paper focuses on the Indonesian to English translation on Vice.com Indonesia in order to study how Indonesian events are presented to the foreign audience through the mediation of translation. It poses three questions: (a) How are news reports written in and about Indonesia are being transmitted in Vice.com Indonesia? (b) What kind of translation process that occurs? and (c) What are the implications of this process to the translated text?

\section{LITERATURE REVIEW}

To begin, this paper looks into the concept of equivalence. This elusive yet widely debated concept in translation studies refers in essence to the relationship between source and target texts (ST and TT). This concept asks, basically, whether the two texts are equal to each other and to what extent. Different translation scholars attempted to answer this differently. Nida (1964), for one, assessed equivalence in terms of formal (structure) and dynamic (functional) equivalence while Koller as cited in Munday (2016) identified as many as five possible equivalence: denotative (equivalence in terms of content translated as is), connotative (equivalence in terms of lexical choices that consider, for instance, language register and emotion), text-normative (equivalence in terms of text function based communicative situations), pragmatic (equivalence in terms of suitability with readers), and formal equivalence (equivalence in terms of form). Compared to Nida's two equivalence model, Koller's is more comprehensive and nuanced. Colina avoids the word equivalence altogether and posits 'signficant degree of resemblance or correspondence' (2015: 12) to describe ST-TT relationship. This paper will see in the discussion chapter whether these concepts are still suitable for news translation.

The second part of this chapter addresses the process employed in news translation. Stetting (1989) and van Doorslaer (2010) preferred the term transediting although Schäffner (2012) disagreed based on her concerns that the latter terminology might imply that translation is a narrow process of word-to-word replacement. This paper follows Schäffner and uses news translation throughout.

Nevertheless, the scholars agree that news translation involves message transformation. In fact, Fujii as quoted in Vuorinen (1999) mentioned message transformation as one of the four gatekeeping functions of news translation - the three other being controlling message quantity, message supplementation, and message reorganization. In a similar vein, Bielsa and Bassnett pointed out that 'news translation entails a considerable amount of transformation of the source text which results in the significantly different content of the target text' (2009: 63). The idea that the resulting target text can be vastly different harks back to André Lefevere's (1992) notion of translation as rewriting.

How, then, does this transformation achieved? Bielsa and Bassnett (ibid.) identified transformation by way of changing title and lead, elimination of unnecessary information, addition of important background information, change in the order of paragraphs, and summarizing information. To a certain extent they are similar to the most common strategies of news translation proposed by Bani (2006), which are cutting or summarizing, inclusion of explanations, generalization, and substitution. The strategies are further complemented by Chen (2011) who identified selection, deletion, addition, combination, synthesis, abridgment, and recomposition. Valdeón (2005), while identifying most of these strategies, also included permutations to refer to message alteration that result in different possible interpretations. To be concise, this paper combines the strategies into:

- Title and lead alteration

- Recomposition/change of paragraph order

- Permutation

- Deletion/omission of paragraph and/or smaller information units

- Addition, including addition of explanations, source quote

- Generalization

- Summarizing/combination/synthesis/abridgment

Stetting, quoted in Valdeón (2015b), referred to the above process as adaptation that consists of three types: adaptation to achieve efficiency in expression, adaptation to have the translated text 
functions in the new context, and adaptation that considers the needs and conventions of the target culture. According to Baumann, Gillespie, and Sreberny (2011), the process of news translation consists of four stages of practices, namely transporting (the capturing of information to be potentially translated texts), translating, transposing/trans-editing, and transmitting. On translating specifically, the authors commented on translation as language-to-language transformation. Bielsa (2016) discussed news translation process, or modification as she termed it in her recent paper, from domesticating-foreignizing point of view proposed by Lawrence Venuti. In short, domesticating a text means ironing out elements that may be unfamiliar for the target readers, while foreignizing maintains those elements. From the standpoint of readability, domesticated texts are easier for the target readers but may offer quasi-sameness of text whereas foreignizing may allow more room for the true voice of and events experienced by others to gain prominence in the text.

\subsection{Previous Research}

Translation scholar Mona Baker has been exploring the issue of translation in journalism in great length especially in the context of translation and news on conflicts. She posited translation as a translatorial act and translators, far from being a neutral language conduit, are embedded to the production and reproduction of conflict narratives and can negotiate meaning through the application of translation techniques (Baker, 2006). Baker's past works in this vein higlighted among others cases of translation from Arabic to English done by the Middle East Media Research Institute (MEMRI).

In "Critical Studies on Terrorism" (2010), Baker provided an explanation on MEMRI's background, which gleaned on how a media's ideology affected the translation it produces. Baker identified MEMRI as a pro-Israel advocacy group and revealed that MEMRI chose to "translate the worst possible examples of Arab, Iranian, and Muslim discourse." Futhermore, Baker pointed how MEMRI's choice of source and target languages reflected the way MEMRI divided the world into two camps, one camp represented threat and the other camp represented the fight against it, respectively. As far as translation techniques, Baker identified that MEMRI often added their own titles or replaced titles with exaggerating ones. As the result of these reconfigurations, the translated texts published by MEMRI frequently offered a different narrative than the original texts.

Indeed, media translation analysis can show that messages that cross between cultures experience re-contextualization, as postulated by Kontos dan Sidiropoulou (2012) who studied news headline translation from English to Greek and found that the headlines they examined were used to communicate different messsages than the original texts. Although Baker and Kontos dan Sidiropoulou showed in details the resulting changes of media translation, the discussion on how these changes might be brought by the translation procedures applied could be found in Dewi (2014). Her paper titled "News Translation from English to Indonesia" pointed out to recontextualization in her investigation of English news to Indonesian, where the use of translation procedures, e.g. particularization, modulation, and generalization created a new nuance in the target texts.

Moreover, Bani's (2006) analysis on the process of translation in the Italian media proved insightful in terms of identifying the issues pertaining translation of the news: (a) the speedy nature of news translation that could be seen in two levels - the speed when translating texts and the speed, or rather immediate readability of the translated texts, (b) the selection of texts to be translated, and the (c) text manipulation, or editing, done to the translation results to ensure they adhere with the media's identity. Bani further identified the types of text manipulation and translation strategies, which will be looked in greater details in the discussion on theoretical framework.

\section{METHOD}

This paper employs descriptive product-oriented approach. The data for this paper were collected from the articles published in November 2018 on VICE Indonesia, focusing on the Indonesianorigin texts and their English translation. 10 pairs of texts were compiled. Each pair was examined and color-coded to identify substitution, elimination, expansion, or condensation on the texts. The 
analyis was performed using comparative method to identify how the strategies affected the translated texts.

\section{RESULTS AND DISCUSSION}

Based on the collected articles, in November 2018 VICE INDONESIA published a total of 248 news articles. Articles translated to Indonesian from English made up the majority of the articles published with a total of 197 articles. The following chart provides an overview of the total articles published by day, divided to English TT to Indonesian ST and Indonesian TT to English ST. The yaxis indicates number of articles and the $\mathrm{x}$-axis indicates the day of the month.

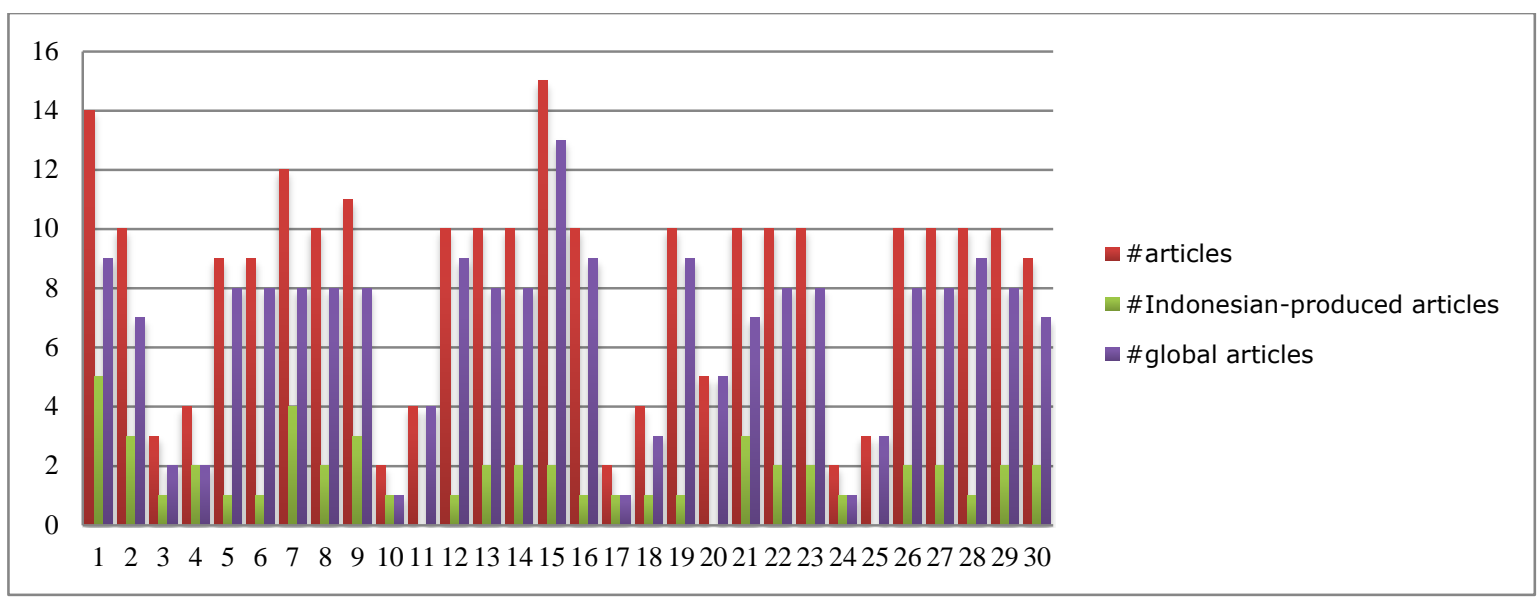

Figure 1. Articles Published November 2018

From 51 articles, this paper selects 10 pairs of Indonesian ST and English TT. The articles represent a broad range of topics from LGBTQ (lesbian, gay, bisexual, trans, and queer), fear of flying, youth deviance, rape, sexism, accidents, child marriage, and government policy. This paper now shall examine the articles based on the three most common strategies found in the cases studied.

\subsection{Alteration of Title and Lead in TT}

The title and lead section of a news article serve as the starting point for readers to anticipate the content of the news they are about to read. They prepare the readers and set the tone of the article. They are also interesting locations where alteration takes place. The alteration occurred across all 10 pairs of Indonesian ST and English TT.

Table 1. ST-TT Title and Lead Comparison

\begin{tabular}{|c|c|c|c|c|}
\hline \multirow[t]{2}{*}{ Article } & \multicolumn{2}{|c|}{ Title } & \multicolumn{2}{|l|}{ Lead } \\
\hline & ST & TT & ST & TT \\
\hline A1 & $\begin{array}{l}\text { Pemerintah Ikut } \\
\text { Membunuh Remaja } \\
\text { Korban KDRT } \\
\text { Pernikahan Anak di } \\
\text { Indramayu }\end{array}$ & $\begin{array}{l}\text { Death of a Teen } \\
\text { Girl Prompts New } \\
\text { Debate Over } \\
\text { Child Marriage in } \\
\text { Indonesia }\end{array}$ & $\begin{array}{l}\text { Upaya revisi UU perkawinan } \\
\text { dan menghapus dispensasi } \\
\text { pernikahan anak ditolak atau } \\
\text { mandeg. Banyak ortu memaksa } \\
\text { anak menikah karena takut zina. } \\
\text { Hasilnya siklus KDRT berujung } \\
\text { maut seperti di Indramayu. }\end{array}$ & $\begin{array}{l}\text { She was only } 15 \text { years } \\
\text { olf. }\end{array}$ \\
\hline $\mathrm{A} 2$ & $\begin{array}{l}\text { Jelang Pemilu, } \\
\text { Indonesia Darurat } \\
\text { Persekusi } \\
\text { Komunitas } \\
\text { Transgender }\end{array}$ & $\begin{array}{l}\text { It Keeps Getting } \\
\text { Worse for } \\
\text { Indonesia's } \\
\text { LGBTQ } \\
\text { Community }\end{array}$ & $\begin{array}{l}\text { Sepanjang November } 2018 \text { saja, } \\
\text { ada tiga kasus penyerangan dan } \\
\text { pengusiran transgender. Satu } \\
\text { daerah menerbitkan perda anti } \\
\text { waria. Komunitas marjinal ini } \\
\text { diduga jadi sasaran persekusi } \\
\text { untuk agenda politik. }\end{array}$ & $\begin{array}{l}\text { This election is pouring } \\
\text { fuel on an already } \\
\text { raging fire. }\end{array}$ \\
\hline A3 & $\begin{array}{l}\text { Aku Berusaha } \\
\text { Mengatasi Obsesi }\end{array}$ & $\begin{array}{l}\text { The } \\
\text { Consequences of }\end{array}$ & $\begin{array}{l}\text { Kenapa kita selalu ikut cemas } \\
\text { dan parno berlebihan setelah }\end{array}$ & $\begin{array}{l}\text { All this news coverage } \\
\text { is taking its toll }\end{array}$ \\
\hline
\end{tabular}




\begin{tabular}{|c|c|c|c|c|}
\hline & $\begin{array}{l}\text { Tak Sehat Terhadap } \\
\text { Kecelakaan } \\
\text { Pesawat }\end{array}$ & $\begin{array}{l}\text { Our Obsession } \\
\text { with Reading } \\
\text { About Plane } \\
\text { Crashes and Other } \\
\text { Tragedies }\end{array}$ & $\begin{array}{l}\text { mengikuti berita pesawat jatuh? } \\
\text { Padahal industri penerbangan } \\
\text { jauh lebih aman dibanding naik } \\
\text { bus atau sepeda motor }\end{array}$ & \\
\hline $\mathrm{A} 4$ & $\begin{array}{l}\text { Pemerintah Selidiki } \\
\text { Tren Anak Muda } \\
\text { Mabuk Pakai } \\
\text { Rebusan Pembalut } \\
\text { Bekas }\end{array}$ & $\begin{array}{l}\text { Indonesian Teens } \\
\text { are Getting } \\
\text { 'Drunk'Off } \\
\text { Boiled Bloody } \\
\text { Menstrual Pads }\end{array}$ & $\begin{array}{l}\text { Pembalut tuh salah satu bahan } \\
\text { pencemar lingkungan terburuk } \\
\text { di Indonesia, eh sekarang } \\
\text { sekaligus jadi bahan teler murah } \\
\text { meriah }\end{array}$ & Wait, What? \\
\hline A5 & $\begin{array}{l}\text { UGM defensif usai } \\
\text { pers kampus } \\
\text { bongkar skandal } \\
\text { pelecehan seksual } \\
\text { mahasiswi Title }\end{array}$ & $\begin{array}{l}\text { Student } \\
\text { Journalists } \\
\text { Expose Alleged } \\
\text { Sexual Assault } \\
\text { Cover-Up at } \\
\text { Indonesian } \\
\text { University }\end{array}$ & $\begin{array}{l}\text { Sikap rektorat UGM yang tidak } \\
\text { tegas membawa dugaan } \\
\text { pelecehan mahasiswi peserta } \\
\text { KKN di Maluku } 2017 \text { ke jalur } \\
\text { hukum, memicu kecaman } \\
\text { publik. Kasus ini mencuat } \\
\text { berkat laporan dari persma } \\
\text { BPPM Balairung. }\end{array}$ & $\begin{array}{l}\text { UGM, one of the } \\
\text { country's best schools, } \\
\text { is being accused of } \\
\text { blaming the victim on a } \\
2017 \text { sexual assault } \\
\text { case. }\end{array}$ \\
\hline A6 & $\begin{array}{l}\text { Ucapan Seksis } \\
\text { Kapolri Bukti } \\
\text { Kampanye \#MeToo } \\
\text { Saja Belum Cukup } \\
\text { Buat Indonesia }\end{array}$ & $\begin{array}{l}\text { Indonesia's Police } \\
\text { Chief Shows } \\
\text { Exactly Why } \\
\text { \#MeToo Is So } \\
\text { Important Here } \\
\text { Too }\end{array}$ & $\begin{array}{l}\text { Jenderal Polisi Tito Karnavian } \\
\text { bilang aparat perlu bertanya } \\
\text { apakah korban 'merasa nyaman' } \\
\text { saat diperkosa. Sebagai } \\
\text { penyintas kekerasan seksual, } \\
\text { ucapannya membuatku makin } \\
\text { yakin gerakan melawan } \\
\text { perkosaan tak bertaji tanpa } \\
\text { perubahan sikap lelaki. }\end{array}$ & $\begin{array}{l}\text { Another day, another } \\
\text { sign that rape culture is } \\
\text { still a huge issue in } \\
\text { Indonesia. }\end{array}$ \\
\hline A7 & $\begin{array}{l}\text { Dua Pekan Usai } \\
\text { Lion Air Jatuh di } \\
\text { Karawang, Ada } \\
\text { Indikasi Sistem } \\
\text { Keamanan Boeing } \\
\text { Bermasalah }\end{array}$ & $\begin{array}{l}\text { It's Been Two } \\
\text { Weeks Since the } \\
\text { Lion Air Crash, } \\
\text { Here's What } \\
\text { We've Learned }\end{array}$ & $\begin{array}{l}\text { Walau evakuasi resmi } \\
\text { dihentikan, KNKT belum } \\
\text { memperoleh posisi blackbox } \\
\text { kedua alias CVR. Kemarin } \\
\text { muncul edaran sistem sensor } \\
\text { Boeing } 737 \text { MAX bermasalah, } \\
\text { bikin geger industri } \\
\text { penerbangan. }\end{array}$ & $\begin{array}{l}\text { Still so many } \\
\text { unanswered questions }\end{array}$ \\
\hline A8 & $\begin{array}{l}\text { Aplikasi Ponsel } \\
\text { Kejaksaan Ancam } \\
\text { Kebebasan } \\
\text { Penganut Agama } \\
\text { Lokal dan } \\
\text { Penghayat }\end{array}$ & $\begin{array}{l}\text { Want to Report } \\
\text { Your Neighbor } \\
\text { for Following a } \\
\text { 'Deviant' Faith? In } \\
\text { Indonesia, There's } \\
\text { an App for That }\end{array}$ & $\begin{array}{l}\text { Kejati Jakarta merilis aplikasi } \\
\text { Smart Pakem untuk menampung } \\
\text { aduan masyarakat soal } \\
\text { kepercayaan dan agama lokal } \\
\text { yang "meresahkan." Kelompok } \\
\text { pro-demokrasi dan kebebasan } \\
\text { beragama segera menolak. }\end{array}$ & $\begin{array}{l}\text { The prosecutor's office } \\
\text { brings you an app one } \\
\text { rights expert warned } \\
\text { could cause "social } \\
\text { disintegration." }\end{array}$ \\
\hline A9 & $\begin{array}{l}\text { Tes Sederhana } \\
\text { Menguji } \\
\text { Kemampuan Kita } \\
\text { Stop Impor Pangan: } \\
\text { Bedah Bahan } \\
\text { Masakan Warung }\end{array}$ & $\begin{array}{l}\text { How Much of } \\
\text { This Food Is } \\
\text { Actually } \\
\text { Indonesian? }\end{array}$ & $\begin{array}{l}\text { Di musim pemilu, makanan jadi } \\
\text { alat ampuh politikus Indonesia } \\
\text { membakar gelora nasionalisme } \\
\text { dengan retorika anti-impor. } \\
\text { Mungkinkah kita berhenti } \\
\text { mengimpor bahan baku dari luar } \\
\text { negeri? }\end{array}$ & $\begin{array}{l}\text { The asnwer might } \\
\text { surprise you. }\end{array}$ \\
\hline A10 & $\begin{array}{l}\text { Aku Naik Feri di } \\
\text { Toba, Lima Bulan } \\
\text { Usai Tragedi KM } \\
\text { Sinar Bangun } \\
\text { Tertutup Bencana } \\
\text { Lain }\end{array}$ & $\begin{array}{l}\text { How Much More } \\
\text { Tragedy Can We } \\
\text { Take? }\end{array}$ & $\begin{array}{l}\text { Adakah pelajaran yang diambil } \\
\text { pemerintah setempat usai } \\
\text { musibah tenggelamnya KM } \\
\text { Sinar Bangun Juni lalu? Inilah } \\
\text { catatanku bertemu mereka yang } \\
\text { masih berduka kehilangan } \\
\text { keluarganya. }\end{array}$ & $\begin{array}{l}\text { What the sinking of a } \\
\text { ferry in Lake Toba, last } \\
\text { June, says about how } \\
\text { Indonesia moves } \\
\text { forward after a tragic } \\
\text { transportation accident. }\end{array}$ \\
\hline
\end{tabular}


Table 1 above clearly illustrates the extent of adaptation and recontextualization on the titles and lead sections. The titles of both ST and TT are concise definitions of the same problem, yet presented in a different light. A1 ST title, for example, straightforwardly places the blame of the death of the teen girl in question to the government; in comparison, the TT title takes a more generic approach and mentions Indonesia as a whole, an example of generalization strategy applied in news translation at the same time. Similarly, A2 ST title focuses on the actor of persecution against the transgender community, i.e. Indonesia as a whole, whereas A2 TT title focuses on the victim's experience. Generalization also occurs here, where the A2 TT title expands the transgender in ST to LGBTQ.

The same pattern can be found in A4 and A5 ST-TT titles. In A5, the ST highlights the defensive attitude of a certain institution while the TT title favors the point of view of the whistleblower of the case. In A4, the ST implies that actions are being taken to address the reported phonemenon, but the TT's choice to focus on the controversial incident suggests that it is a day-to-day occurrence and, by generalizing 'Indonesian teens', widespread. Meanwhile, the personal point of view suggested in A3 ST title is eroded in its TT counterpart with the change of the personal deixis of 'aku' ('I') into 'our' ('kita').

In terms of ST-TT lead, it is noticeable that the lead in the majority of TTs is replaced and significantly more condensed. In half of the lead listed above, they appeal emotionally to the readers, as can be seen from A1, A2, A4, A6, and A5. In others the lead somewhat answers the question implied by the title or complement or further explain the title, as can be seen in A3, A7, A8, A9, and 10. The way the title and lead are translated affect the rest of the article in terms of paragraph configuration, as will be examined in the next section.

\subsection{Recomposition/Change of Paragraph Order, Deletion, Summarizing, and Addition}

Aside from the noticeable differences in title and lead, comparative analysis of content showed that recompositon of paragraphs is prominent throughout all of the articles studied in this paper. In A2, six paragraphs were reorganized in the TT and another six paragraphs were omitted and substituted with new ones. Content-wise, A2 ST and TT delivered their arguments differently in support of their respective title and lead. A2 ST immediately presents an intimate insight into the life of transwoman, while the TT opens with an assertion of the LGBTQ discrimination and how the phenomenon ties to politics.

A3 reveals another interesting example of paragraph recomposition. In line with ST-TT respective title and lead (see earlier discussion), A3 ST starts with and elaborates in details the author's personal experience. It is not until the fifth paragraph that the article starts to depart outwards from the personal experience to searching for the answers to the author's self-proclaimed obsession to plane crash. In comparison, the TT provides only one paragraph, a summary of two paragraphs in the ST, for a personal account and placed as the closing of the article. Made up of a total of 13 paragraphs, the first 12 paragraphs of the TT speaks of the collective experience towards flying and how that experience is affected by airplane crash news. Under its surface, the message conveyed in the article is essentially about the coverage tendency disaster incidences and why the audience is obsessed with tragic news. The ST does this through an elaborate 22 paragraphs. The ST also places quotes from a source, an Indonesian psychologist, prior to other sources from a foreign expert - an order of placement reversed in the TT.

Other articles demonstrate similar paragraph reorganization but A1 and A8 can give us deeper insight and provide the best examples of all of the strategies applied. A1 ST and TT both start by laying out the context of the case, albeit presenting different facts. The ST's first paragraph takes the readers to the scene when the victim was taken to the hospital and died, while the TT gives statistics of child marriage - indicating how pervasive child marriage is in Indonesia. Their subsequent paragraphs from two to five similarly elaborate the victim's background with subtle variance of facts - the ST mentions of a relative of the victim who, upon seeing gruesome images on Facebook, rushed to rescue the victim; the TT mentions of the victim's parents. The information progression on ST then focuses on the legal fight in Indonesia to ban child marriage. In contrast, the TT, after providing more context on child marriage in Southeast Asia, moves on to economic difficulty and social norm. 
TT, para. 10-11:

It's a story of compounding tragedies born from difficult circumstances. Indramayu, a town of about 100,000 on the northern coast of West Java, is one of the poorest places in the province, where as much as 16 percent of residents fall below the government's poverty line of living off about Rp 10,000 (\$0.68 USD) a day.

It's also a town where virginity is seriously prized, to the point where virgin girls are paraded around town in ornate outfits during harvest times in a local tradition called Ngarot. This combination of high poverty rates and an emphasis on a girl's virginity has created an environment where Indramayu has some of the highest rates of child marriage in West Java. (It's also one of the largest sources of sex workers in Indonesia, itself another consequence of the town's unfortunate circumstances.)

While the ST also mentions Indramayu and '...kota-kota lain di Jawa Barat' (para. 10) it lacks the details of population size and income level as well as the social condition in the entire paragraph 11 of the TT. The TT, in para. 17, also states 'But nationwide, this is still a common work-around in Indonesia, where the law often takes a back seat to religious and social norms. It's a loophole those campaigning to end child marriage want the government to close.' In the ST, the culprit of child marriage is the legal loopholes and the government's lack of will to change the situation. Differences can also be found in the sources quoted and the quotes in both articles. In total, there are four sources the articles used - three in the ST and all four in the TT. Furthermore, two sources were quoted differently in ST and TT.

The final article to consider in this analysis is the A8. The article discusses an application developed by the prosecutor's office that, essentially, restricts religious freedom by listing faiths banned in Indonesia and complemented with a 'report' feature that intends to pool information from the public in case they encounter deviant sects. Indonesia recognizes only six religions, and while this is clear to Indonesians, foreign audience may be confused by the context of this app. As the result, the A8 TT adds explanative paragraphs to provide context and insert opinions:

TT, para. 10-12

Oh, cool. So none of these beliefs are going to be destroyed immediately, at least not without an investigation first. What a relief.

Now if you're outside Indonesia, you might be a bit confused here as to why the authorities feel a need to monitor citizen's beliefs like this, so let me give you a quick primer on how the state sees religion....

In Indonesia, your religion is a big part of your life. ...

Moreover, similar to A1, from a total of two sources in ST and TT, the ST quotes only one of the sources and all two sources included in TT. The source that appears in ST and TT is also quoted differently - the quote in ST points to the risk of such app (as a legitimation of persecution), while the quote chosen to appear in the TT questions the premise behind the app.

The above examples represent the transformation of message achieved through the application of news translation strategies. It also appears that the three purposes of adaptation proposed by Stetting are at work in the articles discussed here. By way of summarizing, the TT achieves efficiency in expression. Evidence that shows additions of information in the TT, selection of quotes and sources to quote, and information and/or quote placement represent the attempts to ensure the TTs function well and appeal suitably to the target readers. The approach in this regard is domesticating TTs by highlighting aspects of an event that the author/translator/editor involved in news translation consider most pertinent to the target readers and in ways that the target readers would easily understand. In A9, where the issue food (import) is linked with politics, the TT is domesticated through the condensation of information and elimination of some information on Indonesian politics, while the ST is richer with these details.

With such extensive differences between the STs and TTs it seems that, when referring to the Koller model, only text-normative equivalence is achieved - that is the TTs function effectively as 
news for its target readers. Pragmatic equivalence is achieved to some extent, but the fact that a TT highlights an issue differently than its ST creates ambiguity in this respect, the permutation noted by Valdeón. It can be said, then, that Colina's correspondence is more suitable to describe the STTT relationship in news translation, that the ST-TT resembles one another to a degree but they do not need to be necessarily perfectly equal counterparts. If the TTs' success are to be judged, the assessment will need to be made based on whether they have achieved their goal, or skopos (Vermeer in Munday, 2016), since the traditional notion of equivalence will not be able to aptly evaluate translated news texts as news translation.

\section{CONCLUSION}

As a field of translation, news translation is a unique type of work that is governed by numerous extratextual factors, notably a media's policy on various issues that are then adapted to its editorial rules. As shown by past studies, as different media holds different positions, an original text is rarely entirely preserved when reported in the media. The amount of changes a source text experiences makes it far from ideal for news translation to be discussed from the lens of traditional notion of equivalence, where we tend to look for word or phrase level samenes yet the TT in news translation can present us with a fully reorganized pieces of information.

The analysis shows that the title and lead of ST together serve as an anchor that determines the progression of information conveyed in the body of the TT. It is notably seen in A1, where the ST maintains the focus on the government's failure to reform its policy on child marriage in line with the ST's title, while the TT expands its elucidation on the issue by inserting economic and social problems. Kang (in Schäffner, 2012) called this 're-perspectivization'. It can be considered as the impact of news translation strategies and result in a relatively new construction of reality. It also shows in all case examples especially the title and lead sections of TTs.

Finally, in the same vein as Valdeón, this paper argues that news translation is worth studying by the scholars of translation studies. This paper may be limited in its design and sample, but future studies can improve. News translation can also be researched not only from the strategies applied in translation process but also more critically, e.g. how media ideology influences translation, actors in news translation, or the role of news translation in promoting or resisting certain narratives, using thicker corpus to achieve in-depth results.

\section{REFERENCES}

Baker, M. (2006). Translation and Conflict, A Narrative Account. Oxon: Routledge

(2010). Narratives of terrorism and security: 'accurate' translations, suspicious frames. Critical Studies on Terrorism, 3: $3, \quad 347-364$. DOI: 10.1080/17539153.2010.521639

Bani, S. (2006): An analysis of press translation process. In: Kyle Conway and Susan Bassnett, eds. Translation in Global News - Proceedings of the Conference Held at the University of Warwick - 23 June 2006. Coventry: University of Warwick, Centre for Translation and Comparative Cultural Studies, 35-45.

Baumann, G., Gillespie, M., Sreberny, A. (2011). Transcultural Journalism and the politics of translation: interrogating the BBC World Service. Journalism, 12(2), 135-142. doi: $10.1177 / 1464884910388580$

Bielsa, E. \& Bassnett, S. (2009). Translation in Global News. Oxon: Routledge.

Bielsa, Esperanza. (2015). News Translation: global or cosmopolitan connections? Media, Culture \& Society, 38(2), 196-211. doi: 10.1177/0163443715613635

Chen, Y. (2011). The Translator's Subjectivity and Its Constraints in News Transediting: A Perspective of Reception Aesthetics. Meta, 56(1), 119-144. DOI:10.7202/1003513ar

Colina, S. (2015). Fundamentals of Translation. Cambridge: Cambridge University Press.

Dewi, H.D. (2014). News Translation from English to Indonesia. Journal of English Language of Culture, 4(1), hlm. 35-56. 
Doorslar, van Luc. (2010). Journalism and Translation. In Yves Gambier \& Luc Van Doorslaer (Eds.), Handbook of Translation Studies Volume 1 (180-184). Amsterdam: John Benjamins B.V.

Eka, R. (2016). Media muda VICE Hadir di Indonesia untuk Ekspansi Pertamanya di Asia Tenggara. Retrieved from https://dailysocial.id/post/media-muda-vice-hadir-di-indonesiauntuk-ekspansi-pertamanya-di-asia-tenggara

Gambier, Yves. (2006). Transformations in International News. In Kyle Conway \& Susan Bassnett (Eds.), Translation in Global News, Proceedings of the conference held at the University of Warwick 23 June 2006 (9-22). Coventry: University of Warwick, the Centre for Translation and Comparative Cultural Studies.

Holland, R., (2006). Translation, audience design and discourse (mis)representation. Target, 18(2), 229-259. https://doi.org/10.1075/target.18.2.03hol

-----------., (2013). News Translation. In Carmen Millán \& Francesca Batrina (Eds.), The Routledge Handbook of Translation Studies (332-346). Oxon: Routledge

Kontos, P., \& Sidiropoulou, (2012) M. Socio-political narratives in translated English-Greek news headlines. Intercultural Pragmatics, 9(2), 195 - 224. DOI 10.1515/ip-2012-0012

Lefevere, A. (Ed.). (1992). Translation, History, Culture, a Sourcebook. London: Routledge

Munday, J. (2016). Introducing Translation Studies, Theories and Application. New York: Routledge

Nida, E. (1964). Towards a Science of Translating. Leiden: E.J. Brill.

Reinemann, C., Stanyer, J., Scherr, S., Legnante, G., (2011). Hard and soft news: A review of concepts, operationalization, and key findings. Journalism, 12(2), 221-239. doi: $10.1177 / 1464884911427803$

Renaldi, A. (2018). Pemicu orang-orang Maluku punya keberanian menjalankan profesi penagih utang. Retrieved from https://www.vice.com/id_id/article/7xmave/orang-orang-malukudan-keberanian-menjalani-profesi-penagih-utang

Schäffner, C. (2012). Rethinking $\quad$ Transediting. Meta, $57 \quad$ (4), 866-883. https://doi.org/10.7202/1021222ar

Stetting, K. (1989): Transediting - A new term for coping with the grey area between editing and translating. In: Graham Caie, Kirsten Haastrup, Arnt Lykke Jakobsen, et al., eds. Proceedings from the Fourth Nordic Conference for English Studies. Copenhagen: University of Copenhagen, 371-382.

Valdeón, R. A. (2005). Media Translation in BBCMundo Internet Texts. Revista Canaria de Estu dios Ingleses, Special Issue on Translation Studies, 51, hlm. 105-119.

. (2015a) Fifteen years of journalistic translation research and more, Perspectives, 23:4, 634-662, DOI: 10.1080/0907676X.2015.1057187

(2015b). From Adaptation to Appropriation: Framing the World Through News Translation. Lingua Culture, 1. 51-62. DOI: https://doi.org/10.1515/lincu-2015-0019

Vidyadhana, S. (2017). Pengalaman gay di Indonesia melela pada orangtua. Retrieved from https://www.vice.com/id_id/article/gve8zx/pengalaman-gay-di-indonesia-melela-padaorang-tua

Vuorinen, E. (1994). Crossing cultural barriers in international news transmission: A translational approach. Translation and the (re) location of meaning, selected papers of the CETRA Research Seminars in Translation Studies. pp. 61-82

Wargadiredja, A.T. (2018) Pengakuan sosok di balik produksi film propaganda pengkhianatan G30SPKI. Retrieved from https://www.vice.com/id_id/article/3kepn8/pengakuan-sosok-dibalik-produksi-film-propaganda-pengkhianatan-g30spki 